\title{
SOCIAL ENTREPRENEURS IN LEBANON: AN EXPLORATORY STUDY OF WOMEN ENTREPRENEURS ENGAGED IN THE PROFESSIONAL INTEGRATION OF LOW-SKILLED WOMEN
}

\author{
Inaya Wahidi \\ Faculty of Economics and Business Administration \\ Lebanese University \\ Hadath, Lebanon \\ inaya_wahidi@hotmail.fr \\ Typhaine Lebègue \\ EM Normandie (Metis Lab) \\ 64 Rue du Ranelagh, Paris, France, 75016 \\ tlebegue@em-normandie.fr
}

\begin{abstract}
In a country like Lebanon, where the participation rate of women in the labor force is low, around $24 \%$ in 2014 [1], women social entrepreneurs try to alleviate this problem by targeting Low-skilled women. Our exploratory study aims to identify the motivations of six women social entrepreneurs. These entrepreneurs perceive that low-skilled women need to be reintegrated into society and suffer from gender discrimination at hiring in Lebanon. They also have personal experience that has sparked their interest in the employment of low-skilled women. Interactions with marginalized women and gender discrimination lived throughout their personal and professional lives are also considered as important motivators. Finally, women social entrepreneurs point out that working for the professional integration of low-skilled women gives them personal satisfaction while taking a limited risk. Our qualitative exploratory study was supplemented by a quantitative study among fifty-seven low-skilled women to ascertain the motivations of the women social entrepreneurs who employ them. The results seem to confirm the majority of motivations reported by social women entrepreneurs especially in term of personal satisfaction.
\end{abstract}

Keyword: citizenship theory, entrepreneurial motivation, professional integration of low-skilled women, social entrepreneurship;women social entrepreneurs.

\section{Introduction}

Social entrepreneurship has taken an important place in the academic field of entrepreneurship [2-8].

According to the authors [7], "social entrepreneurship encompasses the activities and processes undertaken to discover, define and exploit opportunities to strengthen social wealth through the creation of new enterprises or the management of existing organizations in a way innovative". However, it seems difficult to determine the extent of this phenomenon, since the production of statistical data does not make it possible to accurately estimate the number of social entrepreneurs [4]. The author [9], reports that women's entrepreneurial activity is relatively more important in the field of social entrepreneurship, but differences appear between countries. While in Hungary and Romania there is a relative predominance of women, Spain and the United Kingdom have a majority of male social entrepreneurs. Some countries show an equivalent number of women and men as social entrepreneurs. According to the authors [10], women social entrepreneurs are more numerous than men social entrepreneurs in several countries, including Lebanon.

Researchers in the field of female entrepreneurship invite the academic community to investigate the interconnections between women's entrepreneurship and social entrepreneurship [11, 12]. Thus, the authors [13] investigated the social entrepreneurship of women in neighborhoods in France and note that the stories testify to a desire for economic emancipation and social motivations deeply rooted in their territory. To our knowledge, there is no research on social entrepreneurs who work on the issue of gender equality. In other words, there are no studies that show the professional integration of low-skilled women through women social entrepreneurs. Our study focuses on this 
issue in Lebanon. Indeed, the number of research in entrepreneurship is low in Lebanon and, to our knowledge, the research in social entrepreneurship is almost absent. An exploratory study identified the motivations of Lebanese social entrepreneurs (male-female confused) [14]. This paper aims to extend this study by focusing on women social entrepreneurs whose objective is to work for the professional integration of low-skilled women.

In this regard, it seems important to note the low participation rate of women in the Arab labor force. ILO figures in 2014 [1], show the following figures: $20 \%$ in Saudi Arabia, 15 \% in Algeria, $24 \%$ in Egypt, $16 \%$ in Jordan, $27 \%$ in Morocco, $29 \%$ in Oman, $14 \%$ in Syria, $25 \%$ in Tunisia, $29 \%$ in Turkey and $24 \%$ in Lebanon. Although the participation rate of Lebanese women in the labor force is relatively small, it should be noted that a significant proportion of them are among the 100 most influential Arab women [15].

In view of these numbers, there is a clear interest in the study of women social entrepreneurs engaged in the professional integration of low-skilled women in Lebanon. According to the authors [16], in Lebanon, women represent $71 \%$ of students enrolled in the social sciences compared to $29 \%$ of men. Moreover, the number of women graduates is $32.67 \%$ in the Lebanese university which is the only public institution of the country and $36.95 \%$ in the private universities (latest statistics of the Central Administration of the statistics in Lebanon in 2007-2008). Women represent 55 per cent of university graduates [17]. If they represent one-third of Lebanese students, women are less able to access positions of responsibility. According to the author [18], women represent $3.1 \%$ of Lebanese parliament, $6.7 \%$ of ministers, $6 \%$ of ambassadors, $28 \%$ of judges and $17 \%$ of trade union councils. Let us note that in Lebanon, companies are more inclined to recruit a man because of the persistent patriarchal model [19]. The World Bank report in 2009 suggests that female entrepreneurs contribute more positively than male entrepreneurs to the employment of women in Lebanon. But there is no research that highlights the contributions of women social entrepreneurs to the employment of low-skilled women in Lebanon, hence the choice of our field of research. This study will therefore answer the question: What are the motivations of women social entrepreneurs engaged in the professional integration of low-skilled women in Lebanon? To answer this question, we will proceed as follows. In a first step, we will present the literature review. In a second step, we will present the experimental procedures of our research. Thirdly, the main results will be proposed. Finally, we will discuss them and present a modeling of the motivations of women social entrepreneurs engaged in the professional integration of low-skilled women in Lebanon.

\section{Literature review}

In this section, we will discuss social entrepreneurship (2. 1) and observe social entrepreneurship adapted to the Lebanese context (2. 2).

\section{1. Some definitions of social entrepreneurship}

The social entrepreneur is defined as one who "seeks to generate resources to maximize the social value created, the social impact of his action" [5]. The authors [20] define the social entrepreneur as "a visionary individual whose primary goal is not to make profit, but to create social value, capable of both grasping, to exploit the opportunities presented to him, to gather the resources necessary for the conduct of his social mission, and to find innovative solutions to the social problems of his community, not covered by the system in place". The authors [3, 8] and [7] observe that social entrepreneurship meets social needs not yet satisfied by the state and/or the commercial sector. These definitions, although interesting, have been developed from examples from developed countries. The particular context of this research, including the absence of the role of the state and the presence of marginalized or excluded women in society, lead us to consider the following definition: "The concept of social entrepreneurship refers to the existence of two fundamental elements: 1 - the discovery and exploitation of business opportunities, through the identification of new problems not yet explored or filled by traditional organizations, and 2 - the creation of social value to individuals in difficulty [7]. 


\section{2. The theory of citizenship adapted to the motivations of women social entrepre- neurs in the Lebanese context}

Most social entrepreneurship studies identify definitions of social entrepreneurship and explain the evolution of the field $[2-4,6,8]$. This research work is therefore a continuation of this work and mobilizes the theory of citizenship to understand the phenomenon of Lebanese women social entrepreneurs. This theory demonstrates the positive character of citizenship, which ensures the inclusion in society of individuals most likely to face discrimination, prejudice or disadvantage [21]. In terms of legal status and civic engagement, "the theory of citizenship permeates discussion of difference and discrimination" [22]. The author [22] who adapted this theory to social entrepreneurship for people with disabilities, note that understanding citizenship plays an essential role in the participation of marginalized populations in society. According to the author [23], civil, political and social rights must be recognized so that full citizenship can be evoked. The author [24] relied on this theory to explain discrimination in countries of patriarchal culture. This author emphasizes fidelity to the head of the patriarchal family and the strong sense of male privilege based on the obligations of women with few rights.

The theory of citizenship highlights the importance of equality in society and thus seems relevant in the context of women social entrepreneurs in Lebanon, particularly in terms of their motivations. Indeed, the rather independent, active and graduate woman in the cedar country, unlike many Arab countries, remains marginalized in comparison to man and does not have the same rights. She has no right to pass on her nationality to her child or her husband, although it is now possible in several Arab countries such as Morocco and Tunisia. Moreover, the unemployment rate continues to evolve in Lebanon and affects $25 \%$ of the working population in 2014 (figure of the Ministry of Labor) [25]. Among women employed, $68 \%$ are single and $29 \%$ are married, compared to $47 \%$ married men and $51 \%$ single men. Thus, the number of married employees is much higher [26]. In a society of patriarchal culture, companies are more inclined to recruit a man [19]. Similarly, in many cases, the design of children leads to a cessation of work, which is why the labor force consists of $24 \%$ in 2014 [27], compared with $76 \%$ of men in Lebanon.

Women entrepreneurs remain a minority in Lebanon. According to the IFC [28], a study of 539 micro-enterprises in Lebanon, shows that business owners men represent $76.4 \%$ against $23.6 \%$ for women. Women entrepreneurs were, however, better trained than male entrepreneurs with $39.2 \%$ of female entrepreneurs with university education, compared with $23.2 \%$ for men. A study of 109 women and 126 men by the World Bank in 2009 reports that in Lebanon women are less likely than men to be entrepreneurs but more likely to be majority shareholders in their companies.

Unfortunately, the literature of social entrepreneurship remains undeveloped, particularly with regard to the motivations of women social entrepreneurs. A study of seventeen social entrepreneurs in Lebanon reveals the following motivations [14]: passion, determination, integrity, enthusiasm, sense of purpose, patience, open-mindedness, curiosity, innovation, creativity, flexibility, social awareness, stubbornness and generosity. The authors point out that entrepreneur did not intend to create a social enterprise, but wanted to overcome the needs they had identified in society. Many of them mentioned personal experience that triggered their interest and willingness to set up the business. The experience of death, war, travel and interaction with marginalized people. Although interesting, this study did not dissociate the motivations of men and women. Yet gender discrimination in Lebanon as well as patriarchal culture is important and triggering factors for the creation of enterprises by Lebanese women [29]. Our work will therefore highlight the motivations of women social entrepreneurs engaged in the professional integration of low-skilled women in Lebanon.

\section{Experimental procedures}

In this part, we will present the type of our research (3. 1), the sample and the data collection (3. 2).

\section{1. The type of our research}

Semi-directional interviews were conducted and questionnaires were administered in order to propose a modeling of the motivations of women social entrepreneurs engaged in the professional integration of low-skilled women in Lebanon. The information will be presented in the following 
by analyzing the qualitative and quantitative data resulting from interviews and questionnaires. Concerning the type of information gathering, we carried out a clinical research by interviewing women social entrepreneurs to collect the necessary data [30]. A pilot interview was conducted with the women social entrepreneur Maud Jabbour, which promotes the professional integration of low-skilled women through its "women to women success" business. This interview allowed us to partially elaborate the questions of our semi-directive interview. Questionnaire data were collected from low-skilled women employed by women social entrepreneurs interviewed to confirm or deny the motivations of these entrepreneurs.

\section{2. Sample and data collection}

In this section, we will present our sample (3.2. 1), the data collection and analysis (3.2.2), the questions of the interview (3.2.3) and the operationalization of the questionnaire variables (3.2. 4).

\section{2. 1. Sample presentation}

Our sample consists of six social entrepreneurs and 57 low-skilled female employees. It seems important to say that the number of NGOs providing seasonal work to rural Lebanese women is rather high to our knowledge, but there are no statistics on women social entrepreneurs in Lebanon. Moreover, there is no legal rule allowing the registration of a company under the name of social enterprise in Lebanon. All social enterprises are registered until now as NGOs or Limited liability company, Ltd. The following table shows the characteristics of the women social entrepreneurs contacted.

Table 1

The main characteristics of the women entrepreneurs interviewed

\begin{tabular}{|c|c|c|c|c|c|c|c|c|}
\hline $\begin{array}{l}\text { Name of } \\
\text { respondant }\end{array}$ & Age & $\begin{array}{c}\text { Marital } \\
\text { status }\end{array}$ & $\begin{array}{l}\text { Number of } \\
\text { children }\end{array}$ & Diploma & $\begin{array}{l}\text { Company } \\
\text { name }\end{array}$ & $\begin{array}{l}\text { Number of } \\
\text { employed } \\
\text { women }\end{array}$ & $\begin{array}{l}\text { Number of } \\
\text { years in } \\
\text { business }\end{array}$ & $\begin{array}{l}\text { Field of } \\
\text { activity }\end{array}$ \\
\hline $\begin{array}{l}\text { Maud Jabbour } \\
\quad(\mathrm{NGO})\end{array}$ & 32 & Single & 0 & $\begin{array}{l}\text { Master inhu- } \\
\text { man ressources }\end{array}$ & $\begin{array}{c}\text { Women to } \\
\text { womensuccess }\end{array}$ & 13 & $\begin{array}{c}4 \\
\text { (since 2012) }\end{array}$ & Restoration \\
\hline $\begin{array}{l}\text { Mabelle Chedid } \\
\text { (NGO) }\end{array}$ & 31 & Married & 2 & $\begin{array}{c}\text { Master in } \\
\text { agriculture } \\
\text { engineering }\end{array}$ & $\begin{array}{l}\text { The foodheri- } \\
\text { tagefoundation }\end{array}$ & 23 & $\begin{array}{c}3 \\
\text { (since 2013) }\end{array}$ & $\begin{array}{l}\text { Traditional } \\
\text { Lebanese food } \\
\text { products }\end{array}$ \\
\hline $\begin{array}{l}\text { Sarah Beydoun } \\
\text { (limited liability- } \\
\text { company, Ltd) }\end{array}$ & 42 & Married & 2 & $\begin{array}{l}\text { Master in } \\
\text { sociology }\end{array}$ & Sarah's bag & 250 & $\begin{array}{c}16 \\
\text { (since 2000) }\end{array}$ & $\begin{array}{l}\text { Handicraft } \\
\text { bags }\end{array}$ \\
\hline $\begin{array}{c}\text { Mme X } \\
\text { (limited liability- } \\
\text { company, Ltd) }\end{array}$ & 55 & Married & 3 & $\begin{array}{l}\text { Bachelor in } \\
\text { business } \\
\text { administration }\end{array}$ & $\mathrm{x}$ & 42 & $\begin{array}{c}17 \\
\text { (since 1999) }\end{array}$ & Crafts \\
\hline $\begin{array}{c}\text { Mme Y } \\
\text { (limited liability- } \\
\text { company, Ltd) }\end{array}$ & 56 & Married & 3 & $\begin{array}{l}\text { Bachelor in } \\
\text { business } \\
\text { administration }\end{array}$ & $\mathrm{y}$ & 31 & $\begin{array}{c}16 \\
\text { (since 2000) }\end{array}$ & Crafts \\
\hline $\begin{array}{c}\text { Mme T. B } \\
\text { (limited liability- } \\
\text { company, Ltd) }\end{array}$ & 52 & Single & 0 & $\begin{array}{l}\text { Bachelor in } \\
\text { business } \\
\text { administration }\end{array}$ & $\mathrm{z}$ & 7 & $\begin{array}{c}17 \\
\text { (since 1999) }\end{array}$ & Restoration \\
\hline
\end{tabular}

Source: Authors

Note that all companies are located in Beirut. But, the women who work with Chedid are mainly in Bekaa, Chouf and Akkar. The number of women working with Beydoun is 200 ex-prisoners outside the company and 50 prisoners in Babbda prison.

Regarding the main characteristics of low-skilled women interviewed: their age varies between 32 and 65 years, $7 \%$ are single, $24.6 \%$ are married with children, $57.9 \%$ are widows with children and $10.5 \%$ are divorced. 


\section{2. 2. Data collection and analysis}

Our research is based partly on the "snowball" method. It started on 30 July 2015 with a non-directive interview with the woman social entrepreneur Maud Jabbour. The contact details of Jabbour were obtained through a student of management sciences at the Lebanese university. She provided contact information for other social entrepreneurs with the same profile as her. It seems important to say that through our family network we were able to contact two social entrepreneurs (Mrs X and Mrs Y) whose names cannot be mention for reasons of confidentiality following their request. These entrepreneurs, having created in the fields of the manufacture of clothes and handicraft items, provide jobs for widows not graduated women in the field of handicrafts. They find that lowskilled, widowed mothers deserve help because they have more responsibility against their children.

We interviewed the six women on the motivations that led them to create a social enterprise. The interviews were carried out by telephone during the months of July and August 2015. The choice of the telephone interview is explained by the agenda of the interviewed women entrepreneurs. We proposed to conduct face-to-face interviews, but respondents preferred telephone interviews. The duration of each interview varies between 40 and 45 minutes. The six interviews conducted thus allowed to generate four and a half hours of work in the field. The processing of the qualitative data was done manually by comparing the speeches of the interviewees.

Quantitative data, through a questionnaire administered face-to-face and by telephone to 57 women employed by the six women social entrepreneurs, supplemented our qualitative data. We have begun administering the questionnaire on June 28, 2016 until August 5, 2016. Given that our study is exploratory, we have chosen an almost equal number of employees. There are 10 employees from each company and seven employees from Mrs T. B company's who has only 7 employees. Concerning the analysis of the quantitative data, simple frequency analyzes followed by the variance test "Anova" via SPSS 17 were carried out. The Anova test can be performed when comparing several samples of the same size or not. In our case, there are six groups or six quasi-equal samples. The Likert scale with five point scale from "strongly disagree" to "strongly agree" was used at the level of independent variables.

\section{2. 3. Interview questions}

First, we gathered general information about women social entrepreneurs and their companies. Second, to identify the motivations of these entrepreneurs engaged in the professional integration of low-skilled women, we asked the following questions:

- What does the term "social entrepreneur" mean to you?

- Why did you choose to recruit only unqualified or low-skilled woman?

- Do they suffer from gender discrimination in hiring in Lebanon?

- What is your goal?

- What is their profile?

- An entrepreneur demonstrates risk-taking, desire for success, independence, time management etc...?

- What describes you most?

- What do you think about the role of the state in the professional integration of low-skilled women in Lebanon?

- Have you had a personal experience that triggered your interest in creating a social enterprise engaged in the professional integration of low-skilled women in Lebanon?

\section{2. 4. The operationalization of the questionnaire variables}

We asked the low-skilled woman about their age and marital status (single, married with children, married without children, widow with children, widow without children, divorced). Then, we asked them to answer our questions by using Likertscalewith five point scale. Our question is the following:

- Do you think that your job manager as a woman social entrepreneur recruited you because:

A. It is a personal satisfaction for her (persatis);

B. Social entrepreneurship does not present a risk for her such as traditional entrepreneurship especially when she recruits low-skilled women (lowrisk); 
C. She perceives that the number of low-skilled unemployed women is high in Lebanon (highlsuw);

D. She already faced gender discrimination in hiring (gendisc);

E. She perceives the absence of the state's role in the professional integration of low-skilled, widowed, raped or prisoned women ... etc (statabs);

F. She attended orientation sessions on social entrepreneurship (socialor);

G. It is an act of charity for her (chartact);

H. She had interactions with you before recruitment (interber);

I. She has experienced family problems (famprob);

J. She experienced gender discrimination in childhood (gendisch).

\section{Results}

In this section, we will present the results of interviews with women social entrepreneurs and the results of the questionnaire administered to their employees.

Women entrepreneurs point out that social entrepreneurship is a "business" to find solutions to social problems and represent a personal satisfaction.They aim to empower low-skilled women "marginalized to their senses" who need help. Their motivation is also a matter of personal satisfaction and not of a need for balance between personal and professional life since 4/6 women entrepreneurs are married with children. In other words, entrepreneurs with children, in general, have embarked on entrepreneurship to manage their time at work (professional life) so that they can spend a good time with their families (personal life).

Time management is a permanent concern for women. The authors [31] highlight the importance of reconciling work and family life by women entrepreneurs and ensure that they constantly have to arbitrate between professional activity and presence with their families. In our research, social entrepreneurs who are married with children observe that it is a personal satisfaction because the balance of time normally desired by non-social entrepreneurs is not too much realized in the social field that requires more energy to spend on their senses.

Chedid says, "Although i am busy and i keep thinking about my work that requires a lot of energy, i can manage my time better than when i worked full-time."

The six social entrepreneurs identify this as a safe job. Two entrepreneurs have attended orientation sessions with social mentors and consider themselves courageous. Contrary to the known concept of risk-taking, Lebanese women social entrepreneurs do not view social entrepreneurship as a propensity for risk-taking. They observed that they were well trained and had enough information to start their projects.

Jabbour observes: "Our work is very tiring, but not risky. The orientation sessions followed by the Al-Ahli group at the "ESA" business school in Lebanon really encouraged me to launch my project which did not require huge start-up capital.

The absence of the role of the state in the support of marginalized women (low-skilled, victims of the violence of their husbands ... etc) constitutes an important motivation for them. For example, Chedid says that "women in homes need independence, are low-skilled and the state cannot even solve these problems, does not care for these women. We do not have electricity 24 hours a day, a water crisis and a waste crisis that started as you know. "The state therefore has difficulties in addressing social problems and the support of marginalized women is not a priority.

The six social entrepreneurs identify that the social need persists. They ensure that there are many low-skilled women or who cannot work outside their homes because they have children. Three entrepreneurs decided to participate in the training of these women by offering orientation sessions in cooking or preparing traditional food products. Their goal is to enable these women to become professionals who can offer their culinary preparations to companies or women who have a job and do not have the time to cook healthy dishes for their children and husbands.

Beydoun is recruiting ex-prisoners who prepare hand-made bags. $\mathrm{X}$ and $\mathrm{Y}$ recruit lowskilled widowed women and teach them to work in crafts. Beydoun asserts that "no one in Lebanon is interested in prisoners, especially ex-prisoners. It is a neglected need in our country that marginalizes these individuals although a good number of them experienced very hard things. All without 
exception note that the unemployment rate of women is high and that gender discrimination in hiring exists in the country of cedars.

Jabbour and Chedid (two entrepreneurs) attended orientation sessions at the ESA (Business School in Lebanon) on social entrepreneurship and corporate social responsibility. Jabbour has crossed many unskilled women who cannot find a job to help their husbands or who are raped by their husbands and want to become financially independent to be able to divorce and stop their "own slavery".

Beydoun declares that the professional integration of ex-prisoners women represented her thesis in master degree in sociology. She insists on the absence of the role of the state at this level. Entrepreneurs ( $\mathrm{x}$ and $\mathrm{y}$ ) note that it is an act of charity. X observes: "I am interested in recruiting unskilled women in need of help. I am particularly interested in low-skilled widows, because i find them weak in our society in particular financially and i exchanged a lot with many of them before launching my project.

$\mathrm{T}, \mathrm{B}, \mathrm{X}$ and $\mathrm{Y}$ relate their experience of gender discrimination experienced during their childhood from their fathers. TB says "my father assured me that $\mathrm{i}$ will not do anything with my diploma that will stick on the kitchen wall when I get married. For that, and as a reaction, i refused marriage and become a social entrepreneur only recruiting non-graduate women who suffer from the discrimination of their parents, and even from their husbands. My father always wanted me to feel that $\mathrm{i}$ am inferior to man. My brothers know today that $\mathrm{i}$ have succeeded in life especially on a professional level". Mrs. X says, "My father always told me that i am different from my brothers. Everything was forbidden except studying, because i was always brilliant at school, otherwise he wanted to forbid me school too. I am not ashamed to say all that and you have guaranteed the anonymity for me. I went to the city of Beirut to pursue my studies at the university after several problems (I will not go into details). Today, i am married to a politician. And i am very satisfied, because $\mathrm{i}$ am brilliant in my field as well as he and i help him sometimes. Moreover, my brothers and my old father are very proud of me at the moment.

Concerning the results of the employee questionnaire, six variables were highlighted by women employees:

- The personal satisfaction felt by the woman social entrepreneur with $49.1 \%$ who agree and $40.4 \%$ who strongly agree;

- The high number of low-skilled unemployed women in Lebanon with $84.2 \%$ who strongly agree;

- The perception of gender discrimination in hiring experienced by low-skilled women with $33.3 \%$ who agree and $54.4 \%$ who strongly agree;

- The absence of the role of the state in the occupational integration of low-skilled women in Lebanon with $40.4 \%$ who agree and $59.6 \%$ who strongly agree;

- Social entrepreneurship is an act of charity with $33.3 \%$ who agree and $66.7 \%$ who strongly agree;

- Interaction with low-skilled women prior to recruitment with $73.7 \%$ who agree.

On the other hand, employees are almost neutral about the absence of risk in social entrepreneurship, the follow-up of orientation sessions by the women social entrepreneurs, the fact of experiencing family problems and gender discrimination experienced by social entrepreneurs during childhood. Taking into consideration the six variables above, the Anova test on the six groups of women employees from six social enterprises shows that the variable "persatis", which means personal satisfaction with regard to the occupational integration of low-skilled women is the only significant variable with a "sig" equal to 0.036 below the threshold of 0.05 . Note that the Anova test was performed because the distribution of the six variables follows the normal distribution following the Skewness and Kurtosis test for which the values vary between -2 and 2 .

\section{Discussion and limitations}

The results of our study show that women entrepreneurs chose to integrate low-skilled women into the workforce because they found that there was a social need and gender discrimination in the country of cedars. Women account for $71 \%$ of students enrolled in higher education in the 
social sciences in Lebanon compared with $29 \%$ for men [16]. It seems important to note that Saint Joseph's University in Lebanon has offered training in social entrepreneurship since 2014, which triggers a reflection on the sex of entrepreneurs taking part in this one-year training and on the gender of social entrepreneurs in Lebanon. For women social entrepreneurs, contrary to the wellknown concept of entrepreneurial risk-taking, social work is considered a risk-free and courageous job, especially for those who have undergone well-organized orientation sessions in Lebanon by Al-Ahligroup,the partner of ESA business school.

Regarding the point of view of employees, the variable "persatis" meaning personal satisfaction in terms of the employability of low-skilled women are the only significant variable depending on Anova test. We decided to present all the motivations detected via social entrepreneurs and low-skilled female employees, as our study remains exploratory. The motivations of women social entrepreneurs who work for the professional integration of low-skilled women can therefore be summarized in the following figure:

\begin{tabular}{|c|c|}
\hline $\begin{array}{l}\text { Motivations } \\
\text { - } \quad \text { Personal satisfaction (+) } \\
\text { The absence of risk-taking }(+) \\
\text { Perception of persistent social need (high rate of } \\
\text { low-skilled unemployed women) }(-) \\
\text { - } \quad \text { Perception of gender discrimination in hiring as } \\
\text { well as for female graduates }(-) \\
\text { - } \quad \text { Perception of the lack of role of the state in the } \\
\text { professional integration of marginalized women, } \\
\text { particularly low-skilled, widowed or having experienced } \\
\text { bad experiences (violence or prison) (-) } \\
\text { - } \quad \text { Follow-up of orientation sessions on social } \\
\text { entrepreneurship and corporate social responsibility }(+) \\
\text { - } \quad \text { Charity Act (+) } \\
\text { - } \quad \text { Personal experience: interaction with marginalized } \\
\text { women, raped by their husbands }(-) \text {; Followed by } \\
\text { orientation sessions on social entrepreneurship in the } \\
\text { context of improving the situation of low-skilled } \\
\text { women (+) } \\
\text { - } \quad \text { The level of past family well-being of the } \\
\text { entrepreneur }(-) \text { Gender Discrimination in Childhood(-) }\end{array}$ & $\begin{array}{c}\text { Social } \\
\text { entrepreneurship } \\
\text { of women working } \\
\text { for the } \\
\text { professional } \\
\text { integration of low- } \\
\text { skilled women in } \\
\text { Lebanon }\end{array}$ \\
\hline
\end{tabular}

Fig. 1. A first modeling of the motivations of women social entrepreneurs working for the professional integration of low-skilled women in Lebanon Source: Authors. Caption: (+) Pull pattern; (-) push pattern

In the modeling above, we have classified the motivations of women social entrepreneurs into push $(-)$ and pull $(+)$ patterns. The pull patterns show the presence of a positive factor that triggered the choice of the insertion of low-skilled women by social entrepreneurs. Push patterns represent a reaction to a negative factor that triggered their choices. In addition, we have highlighted the most significant variable according to the Anova test "personal satisfaction related to the professional integration of low-skilled women".

Concerning the limitations, the qualitative study via interview with 6 women social entrepreneurs and the quantitative study consistent of 57 low-skilled women seem limited. The number of women social entrepreneurs and the number of women employees remained low, but access to interviews was difficult and contact with employees was more than difficult.

\section{Conclusion}

This work made it possible to identify the motivations of women social entrepreneurs working for the professional integration of low-skilled women and thereby to better understand the phenomenon of social entrepreneurship by women. The six women interviewed observe that this 
kind of entrepreneurship gives them personal satisfaction and represents a risk-free work, unlike non-social entrepreneurship. They perceive the high rate of low-skilled unemployed women, the absence of the role of the state in the occupational integration of marginalized women, particularly low-skilled women, widows or having experienced bad things (violence or prison) and discrimination of women in hiring. The meeting of marginalized women, violated by their husbands and the follow-up of orientation sessions on social entrepreneurship in the context of improving the situation of low-skilled women also constituted important levers of motivation.

The results obtained via questionnaire seem to confirm the majority of the motivations of women social entrepreneurs: the personal satisfaction felt by the entrepreneur, the high number of low-skilled unemployed women in Lebanon, perceived gender discrimination in the hiring felt by low-skilled women, lack of role of the state in the professional integration of low-skilled women in Lebanon, social entrepreneurship is an act of charity and interaction with low-skilled women.

On a practical level, better coordination with local businesses is suggested for women social entrepreneurs.This allows the social entrepreneurs to better understand their recruitment needs for non-graduate women and thus improve the skills of low-skilled women in more specific areas. Women social entrepreneurs recruit low-skilled women in the field of cooking, catering and craft industries. We invite them to organize training sessions for clerks, waitresses or reception staff. In this way, these entrepreneurs will increase the employment chances of low-skilled women. Also, women social entrepreneurs will strengthen the role of low-skilled women in Lebanon and contribute even more significantly to economic growth through increased employment.

On a theoretical level, our work partially invalidates the literature related to risk taking by the entrepreneur. Women social entrepreneurs note that social entrepreneurship is risk-free work, unlike non-social entrepreneurship. In this regard, women social entrepreneurs (two entrepreneurs) insist on the importance of well-organized mentoring sessions by mentors in Lebanon, notably by the Al-Ahli Group, an ESA partner. Also, we stress the importance of the theory of citizenship. This theory, which permeates all discussion of difference and discrimination among marginalized populations in society, has been extended to the context of women social entrepreneurs. In this context, the gender discrimination experienced by women social entrepreneurs is potentially a new variable to be inserted in the studies on the motivations of these entrepreneurs.

At the level of limitations, this work is part of an exploratory study and therefore has methodological limitations linked in particular to the difficulty of generalizing these results because of the simple qualitative and quantitative nature of the study. In terms of research prospects, the confrontation of the modeling of women social entrepreneurs working for the professional integration of low-skilled women to all women social entrepreneurs represents a promising track. However, it remains difficult to achieve for contextual reasons related to the lack of cooperation on the part of Lebanese institutions and governmental organizations and the reluctance of women to accept interviews given by their social status. Nevertheless, it is not to be overlooked if we want to better understand the activity of women social entrepreneurs and their motivations in Lebanon.

\section{References}

[1] World Bank Report (2015). Taux de participation à la population active, femmes (\% de la population féminine âgée de 15 ans et plus) (estimation modélisée OIT). Available at: http://donnees.banquemondiale.org/indicateur/SL.TLF.CACT.FE.ZS

[2] Abu-Saifan, S. (2012). Social Entrepreneurship: Definition and Boundaries. Technology Innovation Management Review, 22-27. Available at: http://timreview.ca/article/523

[3] Alvord, S. H., Brown, L. D., Letts, C. W. (2004). Social Entrepreneurship and Societal Transformation: An Exploratory Study. Journal of Applied Behavioral Science, 40 (3), 260-282. doi: $10.1177 / 0021886304266847$

[4] Boncler, J., Hlady-Rispal, M., Papin, C. (2014). L'entrepreneuriat social: une autre façon d'entreprendre. Les Echos Entrepreneurs. Available at: http://business.lesechos.fr/entrepreneurs/idees-de-business/1-entrepreneuriat-social-une-autre-facon-d-entreprendre-59001.php

[5] Boutillier, S. (2008). L'entrepreneur social, un entrepreneur socialisé dans une société entrepreneuriale? Humanisme et Entreprise, 290 (5), 41-60. doi: 10.3917/hume.290.0041 
[6] Draperi, J. F. (2010). L'entrepreneuriat social, un mouvement de pensée inscrit dans le capitalisme. Cestes-Cnam, Recma, Acte 1. Available at: http://recma.org/actualite/lentrepreneuriat-social-un-mouvement-de-pensee-inscrit-dans-le-capitalisme-j-f-draperi

[7] Omrane, A., Fayolle, A. (2010). L'entrepreneuriat social et le développement durable : quels modèles d'affaires dans le champ social ?. XIXème Conférence de l'Association Internationale de Management Stratégique AIMS. Available at: http://www.strategie-aims.com/events/conferences/2-xixeme-conference-de-1-aims/communications/85-lentrepreneuriat-social-et-le-developpement-durable-quels-modeles-daffaires-dans-le-champ-social/download

[8] Thompson, J. L. (2002). The world of the social entrepreneur. International Journal of Public Sector Management, 15 (5), 412-431. doi: 10.1108/09513550210435746

[9] Huysentruyt, M. (2014). Women's Social Entrepreneurship and Innovation. OECD Local Economic and Employment Development (LEED) Working Papers, 2014/01, 24. doi: 10.1787/5jxzkq2sr7d4-en

[10] Terjesen, S., Lepoutre, J., Justo, R., Bosma, N. (2011). Global Entrepreneurship Monitor Report on Social Entrepreneurship. London: Global Entrepreneurship Research Association. Available at: http:// www.gemconsortium.org/report

[11] Hughes, K. D., Jennings, J. E. (Eds.) (2012). Global Women's Entrepreneurship Research: Diverse Settings, Questions and Approaches. Cheltenham/Northampton, U. K.: Edward Elgar, 272. doi: $10.4337 / 9781849804752$

[12] Jennings, J. E., Brush, C. G. (2013). Research on Women Entrepreneurs: Challenges to (and from) the Broader Entrepreneurship Literature? The Academy of Management Annals, 7 (1), 663-715. doi: $10.1080 / 19416520.2013 .782190$

[13] Notais, A., Tixier, J. (2014). L'entrepreneuriat social des femmes dans les quartiers: la triple revanche? Journée AEI - AIREPME, Kedge Business School Marseille. Available at: http://www.ritm.u-psud. fr/wp-content/uploads/2014/03/Pr\%C3\%A9sentationTM2avril14.pdf

[14] Feghali, T., Abuatieh, E., Dandan, J. (2012). Social Entrepreneurship in Lebanon: Contexts and Considerations. American University of Beirut. Available at: http://tonyfeghali.brandyourself.com/Links

[15] Chaouch, R. (2013). Un taux de chômage alarmant mais des femmes en pleine ascension professionnelle dans les pays arabes. Available at: http://www.huffpostmaghreb.com/2013/08/21/chomage-pays-arabes-2012_n_3785606.html

[16] El-Jouni, I., Fong, M. (2010). Gender Statistics in Lebanon Current situation and Future needs Education. Presentation on June 172010 at central administration of statistics in Lebanon. Available at: http://www.cas.gov.lb/images/PDFs/Gender_statistics/2-\%20Use \%20of\%20Gender \%20Statistics\%20-\%20 Education.pdf

[17] Ghosn, N. (2015). Des chiffres choc sur le célibat au Liban. Available at: http://fr.annahar.com/ article/277324-des-chiffres-choc-sur-le-celibat-au-liban

[18] Fong, M. (2010). Women's Empowerment Womens Empowerment and Influence. Presentation on June 172010 at central administration of statistics in Lebanon. Available at: http://www.cas.gov.lb/images/PDFs/Gender_statistics/5-Use\%20of\%20of\%20gender\%20Statistics\%20-\%20Women's\%20Empowerement $\% 20$ and $\% 20$ Influence.pdf

[19] Hamdan, S. (2014). Lancement d'un programme pour soutenir l'employabilité des femmes. Available at: http://www.lorientlejour.com/article/890588/lancement-dun-programme-pour-soutenir-lemployabilite-des-femmes.html

[20] Bacq, S., Janssen, F. (2008). Définition de l'entrepreneuriat social : revue de la littérature selon les critères géographique et thématique. Association Internationale de Recherche en Entrepreneuriat et PME, 9ème CIFEPME à Louvain La-Neuve. Available at: http://web.hec.ca/airepme

[21] Duffy, S. (2010). The Citizenship Theory of social justice: exploring the meaning of personalisation for social workers. Journal of Social Work Practice, 24 (3), 253-267. doi:10.1080/02650533 .2010 .500118

[22] Caldwell, K., Harris, S. P., Renko, M. (2012). The Potential of Social Entrepreneurship: Conceptual Tools for Applying Citizenship Theory to Policy and Practice. Intellectual and Developmental Disabilities, 50 (6), 505-518. doi:10.1352/1934-9556-50.06.505

[23] Marshall, T. H.; Pierson, C., Castles, F. G. (Eds.) (2006). Citizenship and Social Class. The Welfare State Reader. Ed. 2. Cambridge, England: Polity, 30-39. 
[24] Janoski, T. (2014). Citizenship in China: a Comparison of Rights with the East and West. Journal of Chinese Political Science, 19 (4), 365-385. doi: 10.1007/s11366-014-9303-5

[25] Hamdan, S. (2016). Les départs des Libanais ont quadruplé depuis 2011. Le chômage provoque l'émigration. Available at: http://magazine.com.lb/index.php/fr/component/k2/item/14717-les-d\%C3\%A9partsdes-libanais-ont-quadrupl $\%$ C3\%A9-depuis-2011-le-ch\%C3\%B4mage-provoque-1\%E2\%80\%99\%C3\%A9migration?issue_id=219

[26] World Bank Report (2009). Gender Based Differences among Entrepreneurs and Workers in Lebanon. Available at: https://openknowledge.worldbank.org/bitstream/handle/10986/3164/500770ESW0P0 891losed0Feb090201001LB.txt?sequence=2

[27] World Bank Report (2015). Les pays de la Région Moyen-Orient et Afrique du Nord ont besoin d'un nouveau contrat social pour créer des emplois et améliorer les prestations. Available at: http://www. banquemondiale.org/fr/news/press-release/2015/04/15/middle-east-and-north-africa-countries-need-a-newsocial-contract-to-create-jobs-and-improve-services

[28] The International Finance Corporation. The World Bank Group. (2008). Lebanon: a Diagnostic Study on the Demand for Financial Services by Micro and Small Enterprises. Final Report. Available at: http://www.frankfurt-school.de/dms/ias/publications_2008/market_assessment_lebanon/Access\%20to\%20 Finance\%20Lebanon\%20Study.pdf

[29] Levy-Tadjine, T., Sawma, S. (2010). A propos de la désirabilité et de la faisabilité entrepreneuriales perçues pour les jeunes femmes libanaises: une enquête exploratoire. Leabanese Association for the Advancement of Science: LAAS. Jounieh (Kaslik), Liban. Available at: https://hal.archives-ouvertes.fr/ hal-00590374/document

[30] Paturel, R. (2004). Les choix méthodologiques de la recherche doctorale française en entrepreneuriat. Revue de l'Entrepreneuriat, 3 (1), 47-65. doi: 10.3917/entre.031.0047

[31] Delhaye, C., Constantinidis, C., El Abboubi, M., Dieu, A.-M., Pâques, C., Gerkens, S. (2012). La création d'activités par les femmes : freins et leviers. Cahier de recherche $\mathrm{N}^{\circ} 200608$, HEC, Ecole de gestion de l'université de Liège. Available at: http://www.hec.ulg.ac.be/sites/default/files/workingpapers/WP_HECULG_20060812_Delhaye_Constantinidis_Elabboubi_Dieu_Paques_Gerkens_Cornet.pdf (Last accessed: 12.09.2015). 